\title{
Overlapping lung parenchymal and bronchial lesion and hilar lymphadenopathy in pulmonary actinomycosis mimicking lung cancer
}

\author{
Shino Imanishi, ${ }_{1}^{1}$ Tsutomu Shinohara, ${ }^{2}$ Keishi Naruse, ${ }^{3}$ Fumitaka Ogushi ${ }^{1}$
}

${ }^{1}$ Division of Pulmonary Medicine, National Hospital Organization Kochi Hospital, Kochi, Japan

${ }^{2}$ Department of Clinical Investigation, National Hospital Organization Kochi Hospital, Kochi, Japan

${ }^{3}$ Division of Pathology, National Hospital Organization Kochi Hospital, Kochi, Japan

\section{Correspondence to} Dr Tsutomu Shinohara, shinoharat@kochi2.hosp.go.jp

Accepted 13 June 2016

\section{DESCRIPTION}

A 43-year-old man with a 9-year history of schizophrenia presented with productive cough, and was diagnosed with pneumonia of the left lung. As treatment with clarithromycin followed by garenoxacin was not effective, the patient was referred to our hospital. Although physical examination was unremarkable, chest X-ray and enhanced CT showed an irregular-shaped mass in the left inferior lobe, with airway stenosis of the lobar bronchus due to wall thickness and hilar lymphadenopathy (figure 1A-C). The bronchoscopic view of swollen mucosa with nodules was compatible with lung cancer mucosal invasion (figure 2A, B). However, mucosal biopsies revealed tiny clumps including filamentous branching of the bacteria with radial arrangement surrounded by inflammatory cells (figure 2C) and food residues. These pathological findings were compatible with endobronchial actinomycosis. The patient was treated with parenteral ampicillin (6 g/day) for 1 month, followed by oral amoxicillin (1.5 g/day) for 5 months. After the antibiotic treatment, chest CT showed disappearance of the mass shadow, airway stenosis and hilar lymphadenopathy.

The patient had many risk factors for pulmonary actinomycosis, such as pre-existing dental disease, poor oropharyngeal hygiene and smoking. ${ }^{1}$ Although pulmonary actinomycosis occasionally accompanies severe bronchial lesions, bacterial confirmation in sputum or bronchial lavage is difficult. ${ }^{2}$ In addition, a case of Actinomyces lymphadenitis has been reported in which lymph node biopsy revealed the characteristic sulfur granules of Actinomyces. ${ }^{3}$ An overlapping lung parenchymal and bronchial lesion, with hilar lymphadenopathy in pulmonary actinomycosis are rare, but should be considered in the differential diagnosis of lung cancer.
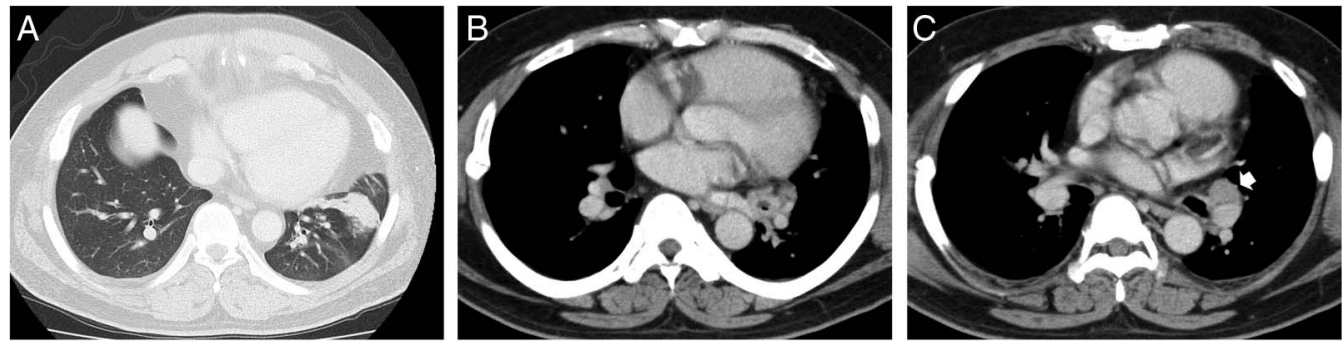

Figure 1 Enhanced CT showing an irregular-shaped mass in the left inferior lobe $(A)$, with airway stenosis of the lobar bronchus due to wall thickness (B) and hilar lymphadenopathy (arrow) (C).
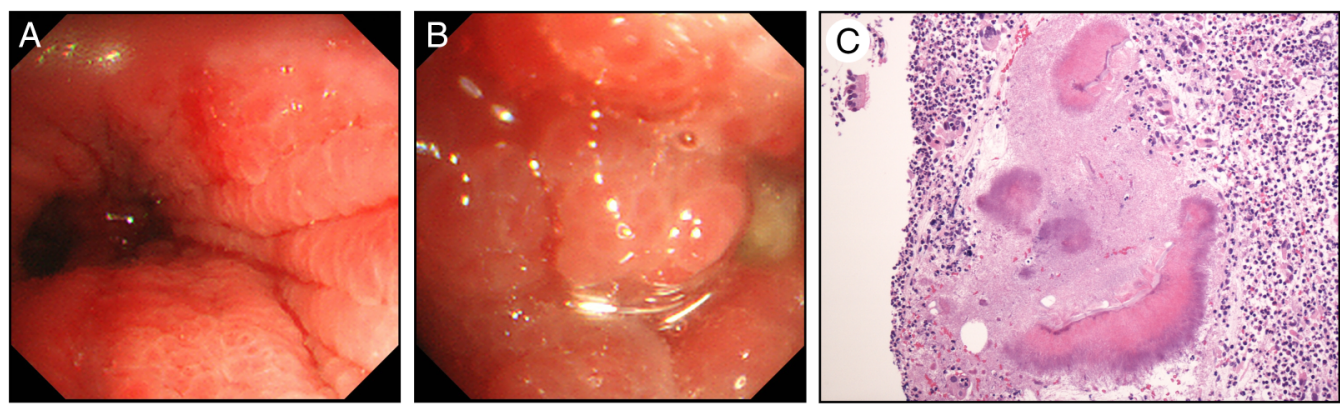

Shinohara T, Naruse $\mathrm{K}$, et al. BMJ Case Rep Published online: [please include Day Month Year] doi:10.1136/ bcr-2016-216308

Figure 2 Endoscopic images of swollen mucosa with nodules of the left inferior lobar bronchus (A and B) and a photomicrograph of H\&E-stained mucosal biopsy, showing a tiny clump including filamentous branching of the bacteria with a radial arrangement surrounded by inflammatory cells (C). 


\section{Learning points}

- Pulmonary actinomycosis should be considered in the differential diagnosis of lung cancer because it can present as either or both of a parenchymal and bronchial lesion and hilar lymphadenopathy.

- This disease is mainly caused by aspiration of oropharyngeal secretions. Therefore, pre-existing dental disease, poor oropharyngeal hygiene and smoking may be risk factors for onset.

- As bacterial confirmation in sputum or bronchial lavage is usually difficult, diagnosis requires additional factors such as characteristic pathological findings and the response to appropriate antibiotic treatment.
Contributors SI drafted the initial manuscript. TS edited and submitted the manuscript. SI and TS were involved in diagnosing and treating the patient. KN performed the pathological studies. FO was the attending physician throughout the disease course.

Competing interests None declared.

Patient consent Obtained.

Provenance and peer review Not commissioned; externally peer reviewed.

\section{REFERENCES}

1 Valour F, Sénéchal A, Dupieux C, et al. Actinomycosis: etiology, clinical features, diagnosis, treatment, and management. Infect Drug Resist 2014; 7:183-97.

2 Katsenos S, Galinos I, Styliara P, et al. Primary bronchopulmonary actinomycosis masquerading as lung cancer: apropos of two cases and literature review. Case Rep Infect Dis 2015:2015:609637.

3 Arik D. Actinomyces lymphadenitis: case report. Turk Patoloji Derg 2013;29:80-2.

Copyright 2016 BMJ Publishing Group. All rights reserved. For permission to reuse any of this content visit http://group.bmj.com/group/rights-licensing/permissions.

BMJ Case Report Fellows may re-use this article for personal use and teaching without any further permission.

Become a Fellow of BMJ Case Reports today and you can:

- Submit as many cases as you like

- Enjoy fast sympathetic peer review and rapid publication of accepted articles

- Access all the published articles

- Re-use any of the published material for personal use and teaching without further permission

For information on Institutional Fellowships contact consortiasales@bmjgroup.com

Visit casereports.bmj.com for more articles like this and to become a Fellow 